\title{
Evolution of Freight Villages and Dry Ports from the Macro Logistics Perspective Based on European Benchmarking 2020
}

\author{
Judit Oláh ${ }^{1,2}$, Steffen Nestler³, Thomas Nobel ${ }^{3}$, József Popp ${ }^{2,4^{*}}$ \\ 1 Institute of Applied Informatics and Logistics, Faculty of Economics and Business, University of Debrecen, Böszörményi út 138. \\ H-4032 Debrecen, Hungary \\ 2 TRADE Research Entity, Faculty of Economic and Management Sciences, North-West University, P. O. B. 1174, \\ Vanderbijlpark 1900, South Africa \\ ${ }^{3}$ Deutsche GVZ-Gesellschaft mbH, Linzer Str. 3, G-28359 Bremen, Germany \\ ${ }^{4}$ Institute of Agribusiness, Faculty of Economics and Social Sciences, Szent István University, Páter Károly utca 1, H-2100 Gödöllö, \\ Hungary \\ * Corresponding author, e-mail: popp.jozsef@szie.hu
}

Received: 13 June 2020, Accepted: 13 August 2020, Published online: 16 August 2021

\begin{abstract}
Being the initiator of the German and European Freight Village ranking, Deutsche GVZ-Gesellschaft (DGG) has the methodical know how to create the benchmarking studies. In this ranking approximately 100 Freight Village locations were analysed and evaluated. The research was based on the generation of an uniform understanding, which was focused on intermodality and the significant distinctive management structures. This data led to a qualitative and detailed overview. Because of the positive response, we were motivated to start the second ranking in 2015, as well as the update in 2019/2020. The results of the ranking show important basics and facts, which demonstrate the importance of the Freight Villages and strengthened their role as central, intermodal logistics nodes. Moreover, the responsible decision makers in the Freight Villages benefit from the results of the benchmarking. Many management companies use their placement in the ranking for public relations activities. Good placements or improvements are important instruments in marketing strategies.
\end{abstract}

Keywords

freight village, dry port, logistics services, benchmarking, macro logistics concept, hinterland

\section{Introduction}

For many years, the European Freight Villages have been playing an important role in the transport sector. They are substantially involved in managing international supply chains (Kot, 2015, Svazas et al., 2019). Logistics trends have a huge impact on all freight villages located in Europe. Nowadays, the importance of issues like digitalization, the shortage of skilled employees, urban logistics and sustainability has increased.

Because of the fact, that the previous European Freight Village Ranking dated already back to five years ago an update was required. It was the goal of the ranking to gain more knowledge about the overall Freight Village (FV) development based on their benchmarking performance (Oláh et al., 2018a; 2018b; 2018c).

It was the intention of the ranking to demonstrate the development and constant change of the logistics landscape in the past five years. Furthermore, it was a chance to find out which suggestions for a successful further development of micrologic concepts in Europe can be derived from the data.

The evaluation criteria for the Freight Village locations were based on the European rankings determined in 2010 and 2015 (Oláh et al., 2018a; 2018b). But there was a change of the evaluation criteria, which will be explained in the following chapter. Now the current third benchmarking is completed and available in this report. 100 out of 300 identified locations were selected for the evaluation.

\subsection{Literature review}

The development of dry ports, an important component of intermodal transport, could play a major role in promoting intermodal transport (Hanaoka and Regmi, 2011). With the increase of containerised traffic, container terminals have started to develop in new locations in the 
hinterland of seaports (Jeevan et al., 2019; Korovyakovsky and Panova, 2011). Development of dry ports reduces customs costs, improves rail-sea intermodal capacity, and minimizes transportation time ( $\mathrm{Ng}$ and Cetin, 2012; Nguyen and Notteboom, 2019; Wang et al., 2016). The emergence of dry ports (offshore ports) is driven partly by proximity to main population centres or industrial areas and partly by the need to support rapidly growing container flows (Beresford et al., 2012; Ślusarczyk, 2017). Several studies confirmed that dry ports play important roles in intermodal freight transport in terms of logistics integration and port regionalization (Kovacs and Kot, 2016; 2017; Notteboom and Rodrigue, 2009; Shi and Li, 2016; Wei et al., 2018).

One of the imperative issues of dry port development in developing economies is location planning (Monios and Wilmsmeier, 2013; Oláh et al., 2018a). Roso (2013) reported that the main performance criteria of the port include geographic location by Nguyen and Notteboom (2016) and physical characteristics. In order to be successful, a dry port should be able to generate enough volume of traffic (Nguyen and Notteboom, 2019; Rodrigue and Notteboom, 2009). Thus, some dry ports are located near production bases or industrial centers in exports-driven economies, or are closely linked to supply chains (hereinafter called "supply chain-oriented" dry ports) in the United States and the European Union (Ng and Cetin, 2012).

A large number of studies have shown that port activities (transportation, handling, storage, treatment and distribution) make ports of crucial importance for the development of regions where they are located Deng et al. (2013) providing comparative advantages to them in terms of trade. More particularly, the port function contributes to increased business activity, which is specialized in the shipping and transport services, while enhancing the business activity indirectly associated with this (banks, insurance companies, tourist agencies) de Langen (2004) and giving the opportunity for relevant stakeholders to invest (Dooms et al., 2015).

However, despite the emerging popularity of the dry port concept, very little research has been done on the assessment of development of dry ports in European countries. The goal of this paper is to support the transfer of positive effects on national and European level that are generated by dry ports on local and regional levels.

\section{Methodology of the benchmarking process}

\subsection{Approach}

The methodical approach includes the creation of questionnaires and an interview guideline as well as the new development of assessment criteria.

\subsection{Definition}

First, considerations on the selection of logistics locations were taken. The main issue was to verify the "transferability", the use of the definition of the German "BundLänder-Grundsätze" on Freight Villages - which were largely shaped - in the European context:

A Freight Village is a building area where commercial transport companies, logistics service providers, complementary service facilities and logistics-intensive production and trade enterprises settle down as independent companies. A FV is linked to several, but at least two transportation modes. A spatial split into functionally structured subareas is permitted.

Freight Villages should contain a transshipment site for combined rail/road or waterway/road/rail transport, which has non-discriminatory access. It is sufficient if the transshipment site is located in proximity to the commercial area. Minimum requirement is the designation of a suitable site for a combined transport terminal.

The establishment of suitable forms of organization (for example management or development companies) is recommended to develop potential synergies.

Freight Villages are primarily macro logistics "roadrail" interfaces and distinguish therefore from classic (inland) ports. The same applies for unimodal logistics parks that are often found near motorways.

Due to the different forms of approaches in the various European countries, a direct transfer of the German definition is not possible. In order to cover a high number of potential Freight Villages and to realize the widest possible analysis of national development levels, a broad interpretation was firstly selected. For that reason, also the "Dry Port Approach" was taken into consideration:

- A Dry Port is an inland intermodal terminal directly connected by road or rail to a seaport and operating as a centre for the transshipment of sea cargo to inland destinations. A recent academic definition of dry ports contends that for a fully developed dry port concept the seaport or shipping companies control the 
rail operations (Roso et al., 2009). Furthermore, the authors contend that dry ports are used much more consciously than inland terminals (Roso et al., 2009). More recently, the term "dry port" has been used in the industry as a marketing tool, perhaps to imply that an inland facility has reached a particular level of sophistication in terms of services offered, such as customs or the presence of Third Party Logistics (3PL) firms within the site and/or an adjoining dry port or similar (see also GVZ in Germany, ZAL in Spain, interporti in Italy) (Wilmsmeier et al., 2011).

- In addition to their role in cargo transshipment, dry ports may also include facilities for storage and consolidation of goods, maintenance for road or rail cargo carriers and customs clearance services. The location of these facilities at a dry port relieves competition for storage and customs space at the seaport itself.

Aiming at realising a detailed analysis of national levels of development, a new understanding of terms was created. It was the goal of the understanding of terms to reach a high number of potential freight villages. Moreover, in the selection of the locations the definition of the European Logistics Platforms Association "Europlatforms" was considered.

The challenge for the selection was the delimitation to:

- Ports: classic inland ports and those functioning only in sea port-related areas.

- Transport industrial parks without intermodal traffic (known as unimodal logistics parks).

Accordingly, the focus will be on following aspects and contents:

- Intermodality with focus on road/rail.

- Establishment of an intermodal transport terminal as key element of the Freight Villages with (if possible) non-discriminatory access.

- Existence of a (neutral/central) management or development company.

\subsection{Development of benchmarking criteria}

Based on the stages of dissociation of benchmarking samples (process and index), 15 clusters were formed for the 2020 ranking. The clusters show a wide range of processes and index in the Freight Villages, which is why the ranking was created based on them (Fig. 1).

The quality of the ranking is shown by the fact that it has succeeded to include soft criteria in the benchmarking process.
These criteria (assigned to the SWOT Analysis) evaluate a varied process on located Freight Villages and accentual special strengths or weaknesses. The evaluation criteria have been created to portray the benchmarking clusters. The criteria are shown in the Table 1.

The following factors form the basis of the evaluation:

- A total of 15 clusters was formed for the 2020 ranking, which contain 38 evaluation criteria. After aspects of sustainability were increasingly included in the ratings in 2015, also digitalization topics were highlighted in the current ranking. These include developments such as the use of Internet of things (IoT) solutions, Information Technology (IT) platforms and blockchain technology. In addition, applications in the field of security technologies were considered in the analyses and evaluations.

- The evaluation criteria (38 factors) were rated/ weighted by their importance. There was a range from "1" (low importance) to "6" (extremely high importance). Consequently, it was possible to ensure, that the ranking focuses on important evaluation criteria, for example the current number of employees. These very important criteria have a special position and relevance in the overall assessment.

The evaluation criteria were evaluated by reference to a four-stage scale (from 0 to 3), which was based on their characteristics of located Freight Villages. The characteristic "0" complies an insufficient assessment, the characteristic "3" conforms to the best assessment. The criteria characteristic denotes different sets of facts, which is why different definitions were created.

- Freight Villages with excellent values "best in class" got special points in the SWOT evaluation. Consequently, it was possible to make a feasible distinction between Freight Villages which were rated close to each other.

- The ascertained average values (benchmarking or Key Performance In-dicators (KPI)) result from information in the questionnaires as well as from inquiries, made by the projects team.

- Creating the ranking, we placed high importance to the intermodality of the Freight Villages ("DNS of the freight villages"). Moreover, the management performance gave important impetus to the ranking, which is why some Freight villages could score highly or lose points.

- The maximum performance to be achieved is 400 points. 
Structural data (1)

FV-settlers and employees (2)

FV - characteristics (3)

Services of the FV (4)

Structure of development companies (5)

Task of the development companies (6)

Position in TEN-T-N (8)

\section{Connection to transportmode (7)}

\section{Intermodel Terminal (9)}

Trends in Logistic (10)

15 Cluster and

38 evaluation criteria

Innovative

Technologies (11)

SWOT-Analysis (12)

Effects / contributions / importance (13)

\section{Estimation of FV-development (14)}

\section{Networks (15)}

Fig. 1 Benchmarking Cluster with evaluation criteria, Source: Own research, 2020

\section{Results}

The following chapter shows the results of the current assessment (2020). It comprises 100 analysed Freight Villages. The ranking is divided in 15 different Clusters containing the individual criteria.

\section{1 "Basic Data" - Cluster 1}

Relevant for the assessment of the Freight Villages are numbers, related to the Freight Village area, the total area, the storage capacity and the area expansion options. Ancillary to the above, the question of the expected time of the complete improvement of the location was also part of the ranking.

\subsubsection{Criterion "Total area in hectares (ha)"}

The ranking shows an average total area of 180 ha, regarding all 100 investigated Freight Villages. The Zaragoza PLAZA (Spain) can still be emphasized, because of its total area of 1.300 ha. In Germany, the Freight Villages in Bremen and Leipzig are with 503 ha and 640 ha of total area significantly above the European average.

\subsubsection{Criterion "Development in \% to total area"}

This criterion shows the proportion of the developed and the total area. The average value of the developed area is about 144 ha. Because of that, the average development status is about $80 \%$ for all European Freight Villages. However, some Freight Villages like the FV Nuremberg are completely developed. The portion of the developed area here is equal to the total area.

\subsubsection{Criterion "Current status of marketed area size in hectare"}

Here, the current settlement status in ha was prompted to be examined. It became clear, that with an average settlement status around $86 \%$, the relation of this criterion compared to the developed area was quite high. 
Table 1 Evaluation criteria FV-Ranking 2020

\begin{tabular}{|c|c|}
\hline 1 & Size of total area in hectares (ha) \\
\hline 2 & Exploitation in $\%$ in relation to total area \\
\hline 3 & Current status of marketed area size in hectares \\
\hline 4 & Opportunities expansion of space/area in hectares \\
\hline 5 & Storage capacity in square meters \\
\hline 6 & Year of complete development and marketing \\
\hline 7 & Current number of companies \\
\hline 8 & Number of companies at final stage \\
\hline 9 & Current number of employees \\
\hline 10 & Final number of employees \\
\hline 11 & Companies per hectare exploited area \\
\hline 12 & Employees per hectare exploited area \\
\hline 13 & Decentralized/centralized FV \\
\hline 14 & Greenfield/Brownfield development \\
\hline 15 & Modality \\
\hline 16 & Number of the FV service facilities \\
\hline 17 & Number of employees of the FV development company \\
\hline 18 & Range of tasks from FV development company \\
\hline 19 & Intensity of tasks \\
\hline 20 & Mode of transport \\
\hline 21 & Positioning in TEN-T \\
\hline 22 & Terminal capacity in loading units \\
\hline 23 & Terminal utilization in loading units \\
\hline 24 & Terminal utilization in $\%$ \\
\hline 25 & Terminal service offers \\
\hline 26 & Logistics trends - consequences for the FV \\
\hline 27 & Implemented IT technologies \\
\hline 28 & Implemented security technologies/management \\
\hline 29 & Strengths - amount \\
\hline 30 & Weaknesses - amount \\
\hline 31 & Opportunities - amount \\
\hline 32 & Threats - amount \\
\hline 33 & Modal transport shift \\
\hline 34 & Urban Logistics \\
\hline 35 & Green Logistics \\
\hline 36 & Importance for the FV-region \\
\hline 37 & Estimation of level of development (own FV) \\
\hline 38 & Networking \\
\hline
\end{tabular}

Source: Own research, 2020

The Freight Village Leipzig, for example has a developed area of 640 ha and a settled area of 639 ha.

\subsubsection{Criterion "Area expansion options in ha"}

The Ranking (2020) shows, that many of the European Freight Villages have area expansion options at their disposal.

The average value of the expansion area is about 70 ha. But in general, it is difficult for Freight Villages in metropolitan areas to obtain sufficient expansion areas. For example, the Freight Villages Berlin City and Nuremberg do not have any possible potential for expansion area/ areal extent. In contrast, the Freight Village Jade Weser Port has an area expansion option of 400 ha.

\subsubsection{Criterion "Storage capacity in the FV"}

The average storage capacity of the European Freight Villages is about $275,000 \mathrm{~m}^{2}$. The location "Zaragoza Plaza" in Spain is still "Best in class" with a storage capacity of 4,270,000 $\mathrm{m}^{2}$. The German frontrunner is the Freight Village Bremen with a storage capacity of 1.5 million $\mathrm{m}^{2}$. The Interporto Torino bears mentioning in the European comparison with a storage capacity of $900,000 \mathrm{~m}^{2}$.

\subsubsection{Criterion "Complete Development/settlement"}

Incidentally, an assessment about the date of the completed development status, as well as an assessment about the complete settlement of the Freight Village area is in demand. Because of inadequate data the span 2020-2025 had to be estimated.

\section{2 "FV settlers/employees" - Cluster 2}

The current number of companies in a FV and the predicted number of companies on the final expansion are important indicators for the development of the European FVs. Moreover, the current number of employees, as well as the current number of employees on the final expansion is considered. Finally, it is the goal to assess the number of employees per ha of settled area.

\subsubsection{Criterion "Number of the current operating companies" and Criterion "Number of the companies on the final expansion"}

In 2020, the average number of companies in the European FVs is about 60. Regarding the final expansion, the average is estimated to be 90 companies. In Germany, FV Nuremberg is noteworthy with 210 located companies. "Best in class" with 350 companies and a predicted number of 450 companies on the final expansion is the Zaragoza Plaza in Spain.

\subsubsection{Criterion "Current number of employees" and Criterion "Number of employees on the final expansion"}

The average number of employees in the European Freight Villages is about 2,300 in 2020. In the "Top 5" of these criteria are two German FV locations (Fig. 2). The Interporto Quadrante Europe Verona (Italy) has 13,000 employees. 


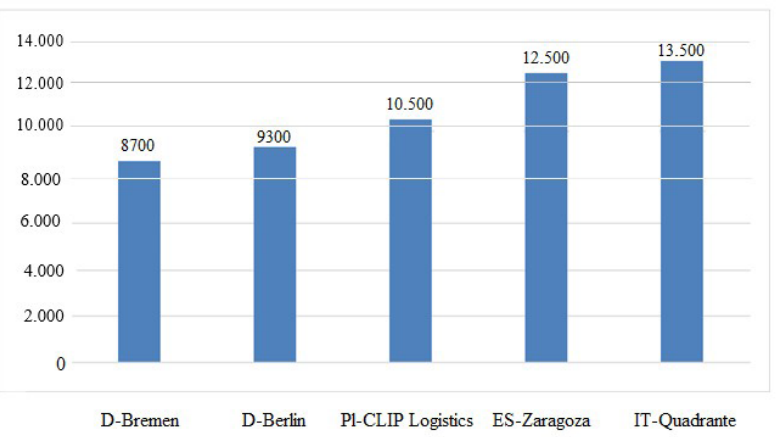

Fig. 2 "TOP 5" in the range of the current number of employees, Source: Own research, 2020

In its final expansion, the average number of employees in Europe will be 4,000 employees. The 2020 ranking results in that there is an average number of 21 employees per ha of marketed settlement area.

Table 2 shows the employment effects of individual logistics facilities in Freight Villages. As expected, the overview shows that higher employment effects are achieved in practice at the property level.

\section{3 "FV Characteristics" - Cluster 3}

In this questionnaire, the distinction between a central and a decentralised FV and "brownfield" or "greenfield", as well as the modality issues were considered.

\subsubsection{Criterion "decentralised/central FV"}

The 2020 ranking shows that central FVs have a noticeable higher overall performance than decentralised FV. The reasons for this are the spatial agglomerate advantages and the higher synergetic effects. About $77 \%$ of the surveyed locations stated, that they have a central location structure of the FV. Consequently, about $21 \%$ have a decentralised location structure.

\subsubsection{Criterion "Greenfield/Brownfield"}

The investigation of the FV areas shows, that a slight amount of the Freight Villages exhibited a "brownfield development" (15\%), despite the fact that a "brownfield development" is very positive from the urban buildings point of view. $40 \%$ of the companies have a divided "greenfield/brownfield development" and just as many have a pure "greenfield development".

\subsubsection{Criterion "Modality"}

As expected, the assessment shows a noticeable higher amount of "bimodal" Freight Villages Locations (road rail). A third of the FVs have three or more transport carriers.

\section{4 "Services in the FV" - Cluster 4}

Based on the cluster "Services in the FV", the number of the activities and service facilities in the European locations were regarded. On average, there are 7 service facilities in the European FVs (Table 3).

\section{5 "Structure FV management companies" - Cluster 5}

Within the cluster "Structure FV Management companies", the responsible institutions for the FV development and establishment, for example the local authorities or FV development or operating companies of the European FV locations were ascertained. Moreover, the numbers of employees inside these institutions were included.

The number of employees within these institutions is on average, about 20 in Europe. This number is higher than the concerning employment values in Germany. A reason for that is the fact that, many FV management companies outside of Germany are owner of areas, which means that they are responsible for the area management.

Table 2 Area (warehouse) and employment key figures of logistics location types

\begin{tabular}{|c|c|c|c|c|c|}
\hline Numbers & $\begin{array}{l}\text { Import } \\
\text { Export } \\
\text { gateway }\end{array}$ & Central distribution & Regional distribution & Production supply & Network logistics \\
\hline warehouse space in $\mathrm{m}^{2}$ & 25,000 & 13,200 & 20,900 & 12,800 & 6,900 \\
\hline $\begin{array}{l}\text { Investment per } 1.000 \mathrm{~m}^{2} \text { in } \\
\text { million } €\end{array}$ & 1.43 & 1.78 & 1.34 & 1.80 & 1.38 \\
\hline Employees per $1.000 \mathrm{~m}^{2}$ & 8 & 10 & 10 & 9 & 15 \\
\hline Share of land plot utilization $\%$ & 48 & 43 & 39 & 42 & 35 \\
\hline Plot area in ha & 5.2 & 3.0 & 5.4 & 3.0 & 1.9 \\
\hline Employees/ha plot area & 37 & 43 & 39 & 37 & 53 \\
\hline $\begin{array}{l}\text { Value contribution per } \\
\text { employee in }\end{array}$ & 45,000 & 41,900 & 30,900 & 70,200 & 32,300 \\
\hline $\begin{array}{l}\text { Value contribution/ha plot area } \\
\text { in Mio € p.a. }\end{array}$ & 1.7 & 1.8 & 1.2 & 2.6 & 1.7 \\
\hline
\end{tabular}


Table 3 Overview FV-Service facilities

\begin{tabular}{l}
\hline Filling station \\
\hline Truck parking area if existing, specify level of classification of secure \\
parking \\
Customs office \\
Personnel services \\
Hotel \\
Social facilities (e.g. sanitary facilities) \\
Waste collection \\
Environmental services (green keeping) \\
Security services \\
Catering (e.g. restaurant, cafeteria) \\
Shopping area \\
Mobility point (e.g. carsharing)) \\
Public transport points \\
\hline Forwarding services \\
Landing spot/service for helicopters \\
Repair service for trucks \\
Post office \\
Liquid gas station Banking \\
Photerence facilities \\
\hline Pouring of freight trains Freight exchange \\
\hline
\end{tabular}

Source: Own research, 2020

About $50 \%$ of the management companies are funded as public private partnership (PPP). Besides that, there are in equal shares "private" and "local" management company models.

\section{6 "Tasks of FV management companies" - Cluster 6}

In the further course, the variety offer of the management company's activities was received. Also, the relevance of the respective activities was identified. On average, 9 tasks were inherited in Europe.

\subsubsection{Criterion "Range of tasks"}

The scope of work of the FV management companies can be widely spread and includes without limitation (Table 4).

\subsubsection{Criterion "Intensity of tasks"}

Because of a self-assessment, the relevance of the practiced management activities and the intensity of tasks were examined. It was possible to ascertain a value from 7 (scale 0-10) Europe-wide.

Accomplishing a Europe wide comparison about the intensity of tasks of the FV management companies, a comparison of the German with the Italian and Spanish FV management companies was made.
Table 4 Overview tasks of the FV management companies

\begin{tabular}{l} 
Acquisition of new tenants/users \\
\hline Site marketing (e.g. participation of trade fairs) \\
Organization of staff training and advanced qualification \\
Development and tenancy of logistics real estates \\
Collaborative logistics initiatives \\
Strengthening of non-logistics value-added-services \\
(e.g. centralization of purchases) \\
Measures to encourage interaction between the companies based \\
in the FV and government departments \\
Technological projects and initiatives
\end{tabular}

\section{Cooperation in research projects other activities}

Financial support for professional schools and colleges for logistic Building management

Cultural initiatives

Location planning (at one's location) o Mobility management

Source: Own research, 2020

In all three countries the support of the planning process of the area, the acquisition of new settlers and the location marketing were very important. The support of the implementation process and the operational phase play an important role mostly by the Italian management companies.

In addition to that, it is notable, that in Italy the organisation of training and further education offers play an essential role.

\section{7 "Connection to various modes of transport" - Cluster 7}

This cluster shows the "direct and indirect" connection to various modes of transport. The assessment was based on the quality, the number and problems of the transport modes.

This criterion is divided in different modes of transport like motorway, railway siding, seaport, inland port, airport and public transport. After the statement of the number of modes of transport an own assessment was created. This assessment was based on a scale of 0 (bad) to 10 (excellent). The majority of the locations have all six mentioned modes of transport and on average, their quality is estimated with an eight.

\section{8 "Positioning in TEN-T" - Cluster 8}

By the positioning in the trans-European network, respectively in the corridor, it was ascertained, if there are one or several corridors on each FV-location (Fig. 3).

Only about $20 \%$ of the locations are situated outside of the trans-European network. About $80 \%$ of the European locations are located inside one or several corridors. On average, the locations are integrated in two corridors. 


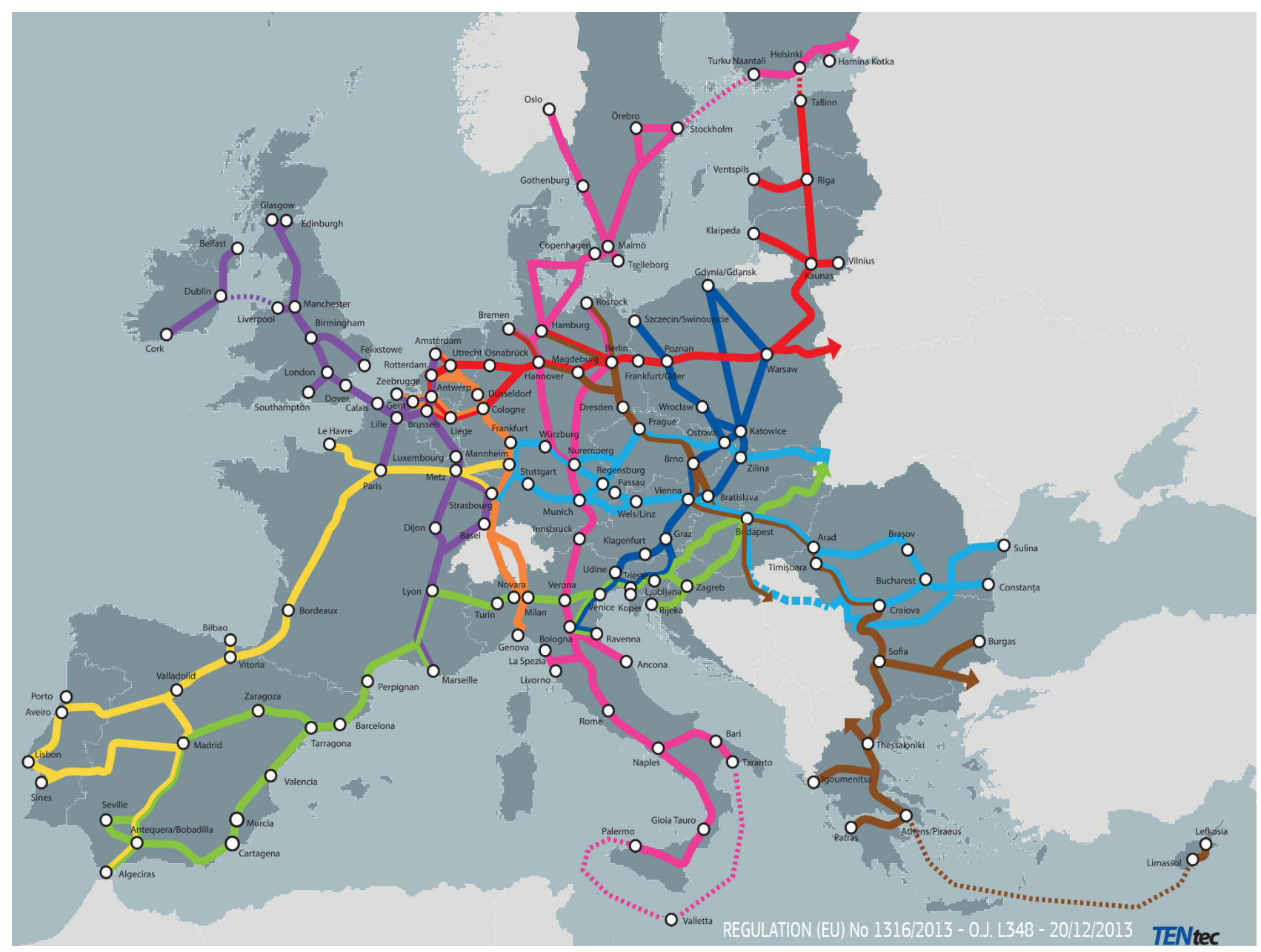

Fig. 3 TEN - Trans-European Network

\section{9 "Intermodel terminal" - Cluster 9}

Intermodality is essential for FVs. Intermodal transshipment terminals are a definitional characteristic of Freight Villages. It is also a condition for an intermodal transport connection of the $\mathrm{FV}$ and the realisation of combined traffic.

\subsubsection{Criterion "Terminal capacity"}

Analysing the terminal capacity, the enpacity of the loading units (TEU converted in LTE) was indicated. These may include containers swap bodies and semi-trailers. Impressive is the capacity volume of the Interporto Quadrante Europe Verona (Italy) with 800,000 loading units. The average value in Europe is a terminal capacity of 135,000 loading units (LU).

\subsubsection{Criterion "Terminal workload in loading unit"}

The terminal workload, measured with the help of the absolute number of loading units, the average value of the European FV locations lays around 75,000 LU. Taking into account, the terminal capacity, the location "Quadrante Europe" (Italy) is leading with 730,000 LU.

\subsubsection{Criterion "Terminal workload/utilization in \%"}

The terminal workload in percentage was calculated in relation to capacity. An average of $\mathbf{5 5} \%$ was determined. Various locations, for example the FV Leipzig and the FV Augsburg show a utilization of up to $100 \%$.

\subsubsection{Criterion "Terminal service"}

Furthermore, data for supplementary services in the combined traffic were determined. These facilities, which are provided by the terminal service, consists of a container depot, container repair, container packing, trucking and the storage of dangerous sub-stances or the purification of tank container. On average, five of the six services, mentioned in the questionnaire, are offered in Europe. It becomes clear, that in most FVs a well developed service exists. Furthermore, there are some locations, which offer all services, including some auxiliary services like plugs for refrigerated containers or bulk handling.

Table 5 shows the listing of all stated services for the combined traffic of the European locations, including the six-recorded services. 
Table 5 Terminal services in the European FVs (TOP services)

\begin{tabular}{l}
\hline Terminal services \\
\hline Container depot \\
Container repair \\
Container packing \\
Trucking (Pre- and On-Carrying) \\
Storage of hazardous materials \\
Cleaning of tank containers \\
\hline Other services \\
Load securing/weight (SOLAS agree) \\
Reefer plugs \\
RoRo equipment \\
Fumigation container \\
Bulk loading \\
Agency services \\
Wagon repair \\
Cargo exchange in combined traffic \\
\hline Source: Own research, 2020
\end{tabular}

Source: Own research, 2020

\subsection{0 "Logical trends and their impacts on the FV" - Cluster 10}

This cluster contains the logistics trends and their impacts on the individual Freight Village. For example, this cluster is about the risk assessment regarding the cybercrime and the risks on the basis of climate change.

\subsubsection{Criterion "Relevance of trends for the own location"}

Incidentally, the persons responsible for the FV were encouraged to assess the relevance of the trends for their own location. The scale was defined from 0 (no importance) to 10 (high relevance). On average, 6 points were determined in Europe. The assessment of the criteria took place individually, for example in dependence on the number of trends and on the assessment of importance of each trend. Generally speaking, a low importance gave a positive assessment. Because of the fact, that a high importance could be positive (Green logistic) as well as negative (nature risks), the importance was assessed individually.

The trends indicated in the ranking were:

- Increasing volatility within the flows of goods

- Demographic change through aging societies (e.g. effects on labour-intensive logistics operations or lack of skilled workers like drivers)

- Sustainability ("Green Logistics")

- Rising risks from natural catastrophes (climate change)

- Rising risks from cybercrime

- New challengers and competitors.
The data collection showed that the topic of "sustainability" ("green logistics") is of great importance to the respondents. Many FV managers have also assessed the topics "demographic change" and "increasing volatility within the flow of goods" with a high degree of importance.

\subsection{1 "Innovative technologies and digital transformation" - Cluster 11}

The digital transformation in the past years has also found his way in the logistics sec-tor. In this cluster, for example new technologies were prompted as well as the status quo of their current implementation.

\subsubsection{Criterion "Implementation of digital and innovative security technologies"}

In Europe on average, about 7 ( $0-10$ scale) points were ascertained. The evaluation of the criteria was followed individually but in dependence on the numbers of the mentioned technologies as well as in the assessment of each technology.

Innovative technologies, which are listed in this topic:

- Free WIFI service,

- Optical Fibre development,

- IoT,

- Big Data Processing,

- Blockchain systems,

- Integration in a data interchange platform,

- Security technologies.

The relevance of the "optical fiber development" was striking here. This was mentioned by the majority of respondents and was rated with a high to very high score in terms of its importance.

\subsection{2 "SWOT-analysis" - Cluster 12}

The SWOT analysis contributes to visualise the strengths (Criterion 28) and the weaknesses (Criterion 29), as well as the chances (Criterion 30) and risks (Criterion 31) Regarding the analysis of criteria the strengths and weaknesses as well as the chances and risks were ascertained and provided with additional points. It was the goal of this cluster to identify and emphasize special developments/tendencies and assumptions. Overall, the inquiry shows different predictions. The four most frequently mentioned statements were summarised in the Table 6 . It illustrates in which areas the FV responsible of the "Top 20" see strengths/ weaknesses and chances/risks at their own location. 
Table 6 SWOT-analysis of the European FVs

\begin{tabular}{l}
\hline Criteria "Strengths" \\
\hline Centrality/position of the FV \\
Good traffic connection/infrastructure \\
Intermodal hub/services \\
Services (e.g. security parking) \\
\hline Criteria "Weaknesses" \\
Missing/limited area expansion options \\
Missing/defective infrastructure (e.g. highway, electrification) \\
Low economic power \\
Missing/defective services \\
\hline Criteria "Chances" \\
Network expansion/interior \\
Expansion options of areas \\
Terminal expansion/refurbishment \\
\hline Criteria "Risks" \\
Shortage of skilled workers \\
Trade conflicts \\
Increasing competition because of other locations \\
Climate impacts/risks (e.g. tidal, low water) \\
\hline Source: Own research,
\end{tabular}

Source: Own research, 2020

Regarding the weaknesses, the consequences of an increasing shortage of areas of the FV have to be mentioned. Because of the limited expansion option, a cluster formation is taken into account. Inside of the risks analysis, it becomes clear, that the local competitive (area) just off the $\mathrm{FV}$ is assumed as being problematic.

\subsection{3 "Self-assessment of effects/contributions/ importance of the FV" - Cluster 13}

Finally, the interviewees were asked for a self- assessment of effects, contributions and importance of the respective FV location. By reference to a scale from 0 (no or limited) to 10 (very high), an assessment in the criteria "modal shift", "Urban logistics", "Green logistics" and "Importance of the FV for the region" was delivered.

\subsubsection{Criterion "Modal shift"}

The modal contributions of the modal shift from road to rail, respectively inland water-way was on average, evaluated with an 8.2, which means that the contributions find greater acceptance. The modal shift manifests one of the most important "brand essences" of the European FVs thought.

\subsubsection{Criterion "Urban logistics"}

The reduction of traffic in the urban area was on average, assessed with a 7.4, by reference to a scale from 0 (very low) to 10 (very high). Occasionally, the increasing activities of the locations fall within the scope "Urban logistics".
Projects/initiatives show that the topic of "Urban logistics" - despite the background of the current climate protection discussions - has already gained in concrete importance in the FV.

\subsubsection{Criterion "Green logistics"}

The importance of the "Green Logistics" was given a low valuation. On average, the contribution, which FV locations award themes like energy efficiency is about 6.6 on a scale of 1 to 10 .

Nevertheless, the significance is noticeable, because not only concrete measures, but also the position of the FV plays a role.

\subsubsection{Criterion "Importance of the FV as a whole for the region"}

The importance of the FV as a whole that means its impact on traffic, employment and environment for the region, was on average, evaluated with an 8.6. This shows the high significance of the FV inside the region and that they wield influence on the region. The location is often referred to as a "lighthouse function", for the region.

\subsection{4 "Development assessment" - Cluster 14}

The FV management company assessed the development status of their location, inside their own country and inside Europe. The average self-assessment is quite high with a score of 8.2 (on a scale of 1 to 10).

Table 7 shows the comparison of the average assessment of the development status in the years 2010, 2015 and 2020 (Haasis et al., 2014; Mackentun et al., 2013; Nestler and Nobel, 2016). A positive tendency, including the contribution of the development status assessment of the own FV (+0.7) can be indicated.

\subsection{5 "Networking" - Cluster 15}

At this point of the assessment, the membership in a national FV- association was asked for.

\section{Conclusion and recommendation}

The knowledge gained in the ranking of the European FV locations is presented in Table 8. Compared to the first

Table 7 Development status in comparison of the years 2010/2015/2020

\begin{tabular}{lccc}
\hline & 2010 & 2015 & 2020 \\
\hline FV Development status/overall for Europe & 5.8 & 6.5 & 6.6 \\
FV Development status for the own country & 5.2 & 6.2 & 6.9 \\
FV Development status/for the own FV & 6.3 & 7.5 & 8.2 \\
\hline
\end{tabular}

Source: Own research, 2020 
Table 8 "TOP 20" of the 2020 Ranking

\begin{tabular}{|c|c|c|}
\hline & Freight Villages & $\begin{array}{l}\text { Performance points } \\
\quad(\max .400)\end{array}$ \\
\hline 1 & D - Bremen & 362 \\
\hline 2 & IT- Quadrante Europa Verona & 361 \\
\hline 3 & D - Nürnberg & 347 \\
\hline 4 & ES - Zaragoza & 346 \\
\hline 5 & D - Berlin Süd Großbeeren & 336 \\
\hline 6 & PL - CLIP Logistics & 333 \\
\hline 7 & IT - Parma & 328 \\
\hline 8 & IT - Bologna & 322 \\
\hline 9 & A - Cargo Center Graz & 305 \\
\hline 10 & IT - Padova & 302 \\
\hline 11 & IT - Nola & 301 \\
\hline 12 & D - Berlin West Wustermark & 300 \\
\hline 13 & FIN - RRT Kouvola & 297 \\
\hline 14 & IT - Torino & 294 \\
\hline 15 & D - Leipzig & 292 \\
\hline 16 & D - JadeWeserPort & 291 \\
\hline 17 & A - Ennshafen Port & 280 \\
\hline 18 & $\mathrm{H}-\mathrm{BILK}$ & 279 \\
\hline 19 & D - Erfurt & 275 \\
\hline 20 & ES - ZAL Barcelona & 273 \\
\hline
\end{tabular}

Source: Own research, 2020

two European rankings in 2010 and 2015, there was a shift in the 2020 ranking among the "Top 3". The top locations in Europe were and are currently GVZ Bremen (rank 1), Interporto Verona (rank 2) and GVZ Nuremberg (rank 3).

Seven German locations were able to establish themselves in the "TOP 20": GVZ Berlin Süd Großbeeren (5), the GVZ Berlin West Wustermark (12), the GVZ Leipzig (15), the GVZ Jade Weser Port (16) and the GVZ Erfurt (19).

In addition to the German FV, the Italian Interporti are among the leading lo-cations in Europe and thus continue the successful international performance standards.

Spain and Austria are still considered one of the pioneers of the successful establishment of the freight village idea. Furthermore, there has also been a strong development in Poland, Hungary and Finland.

\section{References}

Beresford, A., Pettit, S., Xu, Q., Williams, S. (2012) "A study of dry port development in China", Maritime Economics \& Logistics, 14(1), pp. $73-98$.

https://doi.org/10.1057/mel.2011.17

de Langen, P. (2004) "The Performance of Seaport Clusters; A Framework to Analyze Cluster Performance and an Application to the Seaport Clusters of Durban", Rotterdam and the Lower Mississippi, (No. ERIM PhD Series; EPS-2004-034-LIS), ERIM Ph.D. Series Research in Management, Erasmus University Rotterdam.
Among the "league climbers" of the ranking is the Polish Freight Village CLIP Poznan.

The ranking demonstrates that the European freight village landscape is constantly changing and continues to develop. It is worth noting that more European countries are currently in the final "TOP 10". If Italian and German locations dominated the field in the past, five countries are currently represented there.

Compared to the previous rankings, the level of development of the freight village locations has increased once again in the individual countries, but also in Europe as a whole.

It also became clear that many Freight Village sites in Europe are significantly relevant for the logistics operation of their surrounding region. Therefore, it is not surprising that the Freight Village managers often spoke in the survey about their location as a "lighthouse function" for the region.

The positive development of the European Freight Villages is reflected in many individual aspects. In particular, high employment figures, existence of logistics-oriented service facilities and, last but not least, the excellent work of many committed Freight Village management institutions are to be mentioned.

Despite all the positive findings of the ranking, it cannot be disregarded that it is necessary to address some challenges in the future and also cannot close the view to risks and possible negative influences. For example, the lack of area expansion options for the sites is an enormous handicap for further development. The shortage of skilled employees in logistics is now also regarded as a European challenge, as well as negative effects due to climate change and possible trade conflicts caused.

On the other hand, Freight Villages benefit from intensive networking among themselves, existing as well as future synergy effects and therefore will continue to position themselves successfully in the logistics market.

Deng, P., Lu, S., Xiao, H. (2013) "Evaluation of the relevance measure between ports and regional economy using structural equation modeling", Transport Policy, 27, pp. 123-133.

https://doi.org/10.1016/j.tranpol.2013.01.008

Dooms, M., Haezendonck, E., Verbeke, A. (2015) "Towards a meta-analysis and toolkit for port-related socio-economic impacts: a review of socio-economic impact studies conducted for seaports", Maritime Policy \& Management, 42(5), pp. 459-480. https://doi.org/10.1080/03088839.2014.944238 
Haasis, H.-D., Küßner, N., Mackenthun, F., Nobel, T. (2014) "Anforderungen an das GVZ des 21. Jahrhunderts: Dokumentation der Fachtagung am 14. Mai 2014 in Bremen" (Requirements for the GVZ of the 21st Century: Documentation of the Symposium on May 14, 2014 in Bremen), vol. 4, wvb Wissenschaftlicher Verlag, Berlin, Germany. (in German)

Hanaoka, S., Regmi, M. B. (2011) "Promoting intermodal freight transport through the development of dry ports in Asia: An environmental perspective", IATSS Research, 35(1), pp. 16-23.

https://doi.org/10.1016/j.iatssr.2011.06.001

Jeevan, J., Chen, S.-L., Cahoon, S. (2019) "The impact of dry port operations on container seaports competitiveness", Maritime Policy \& Management, 46(1), pp. 4-23. https://doi.org/10.1080/03088839.2018.1505054

Korovyakovsky, E., Panova, Y. (2011) "Dynamics of Russian dry ports", Research in Transportation Economics, 33(1), pp. 25-34. https://doi.org/10.1016/j.retrec.2011.08.008

Kot, S. (2015) "Cost Structure in Relation to the Size of Road Transport Enterprises", Promet-Traffic \& Transportation, 27(5), pp. 387-394. https://doi.org/10.7307/ptt.v27i5.1687

Kovacs, G., Kot, S. (2016) "New logistics and production trends as the effect of global economy changes", Polish Journal of Management Studies, 14(2), pp. 115-126. https://doi.org/10.17512/pjms.2016.14.2.11

Kovács, G., Kot, S. (2017) "Economic and social effects of novel supply chain concepts and virtual enterprises", Journal of International Studies, 10(1), pp. 237-254. https://doi.org/10.14254/2071-8330.2017/10-1/17

Mackenthun, F., Nestler, S., Nobel, T. (2013) "Grüne Güterverkehrszentren (GVZ) in Deutschland: Ein erster Einblick" (Green Freight Traffic Centers (GVZ) in Germany: A First Look), vol. 3, wvb Wissenschaftlicher Verlag, Berlin, Germany. (in German)

Monios, J., Wilmsmeier, G. (2013) "The role of intermodal transport in port regionalisation", Transport Policy, 30, pp. 161-172. https://doi.org/10.1016/j.tranpol.2013.09.010

Nestler, S., Nobel, T. (2016) "Güterverkehrszentren (GVZ) in Europa: Ergebnisse des zweiten europäischen Rankings 2015" (Freight Villages (FV) in Europe - Results of the second European Ranking 2015), vol. 6, wvb Wissenschaftlicher Verlag, Berlin, Germany. (in German)

Ng, A. K., Cetin, I. B. (2012) "Locational characteristics of dry ports in developing economies: some lessons from Northern India", Regional Studies, 46(6), pp. 757-773.

https://doi.org/10.1080/00343404.2010.532117

Nguyen, L. C., Notteboom, T. (2016) "A Multi-Criteria Approach to Dry Port Location in Developing Economies with Application to Vietnam", The Asian Journal of Shipping and Logistics, 32(1), pp. 23-32.

https://doi.org/10.1016/j.ajs1.2016.03.003

Nguyen, L. C., Notteboom, T. (2019) "The relations between dry port characteristics and regional port-hinterland settings: findings for a global sample of dry ports", Maritime Policy \& Management, 46(1), pp. 24-42.

https://doi.org/10.1080/03088839.2018.1448478

Notteboom, T., Rodrigue, P. (2009) "Inland terminals within North American and European supply chains", Transport and communications bulletin for Asia and the Pacific, 78(1), pp. 1-39.
Oláh, J., Nestler, S., Nobel, T., Harangi-Rákos, M., Popp, J. (2018a) "Development of dry ports in Europe", International Journal of Applied Management Science, 10(4), pp. 269-289.

https://doi.org/10.1504/IJAMS.2018.10010622

Oláh, J., Nestler, S., Nobel, T., Popp, J. (2018b) "International Characteristics of the Macro-Logistics System of Freight Villages", Periodica Polytechnica Transportation Engineering, 46(4), pp. 194-200.

https://doi.org/10.3311/PPtr.11656

Oláh, J., Nestler, S., Nobel, T., Popp, J. (2018c) "Ranking of Dry Ports in Europe - Benchmarking", Periodica Polytechnica Transportation Engineering, 46(2), pp. 95-100.

https://doi.org/10.3311/PPtr.11414

Rodrigue, J.-P., Notteboom, T. (2009) "The terminalization of supply chains: reassessing the role of terminals in port/hinterland logistical relationships", Maritime Policy \& Management, 36(2), pp. $165-183$. https://doi.org/10.1080/03088830902861086

Roso, V. (2013) "Sustainable intermodal transport via dry ports-importance of directional development", World Review of Intermodal Transportation Research, 4(2-3), pp. 140-156. https://doi.org/10.1504/WRITR.2013.058976

Roso, V., Woxenius, J., Lumsden, K. (2009) "The dry port concept: connecting container seaports with the hinterland", Journal of Transport Geography, 17(5), pp. 338-345. https:/doi.org/10.1016/j.jtrangeo.2008.10.008

Shi, X., Li, H. (2016) "Developing the port hinterland: Different perspectives and their application to Shenzhen Port, China", Research in Transportation Business \& Management, 19, pp. 42-50. https://doi.org/10.1016/j.rtbm.2016.05.004

Ślusarczyk, B. (2017) "Prospects for the shared services centers development in Poland in the context of human resources availability", Polish Journal of Management Studies, 15, pp. 218-231. https://doi.org/10.17512/pjms.2017.15.1.21

Svazas, M., Navickas, V., Krajnakova, E., Nakonieczny, J. (2019) "Sustainable supply chain of the biomass cluster as a factor for preservation and enhancementof forests", Journal of International Studies, 12(2), pp. 309-321.

https://oi.org/10.14254/2071-8330.2019/12-2/20

Veres-Homm, U., Kübler, A., Weber, N., Cäsar, E. (2015) "Logistikimmobilien - Markt und Standorte 2015" (Logistics Real Estate - Market and Locations 2015), Fraunhofer Verlag, Stuttgart, Germany. (in German)

Wang, G. W., Zeng, O., Li, K., Yang, J. (2016) "Port connectivity in a logistic network: The case of Bohai Bay, China", Transportation Research Part E: Logistics and Transportation Review, 95, pp. 341-354.

https://doi.org/10.1016/j.tre.2016.04.009

Wei, H., Sheng, Z., Lee, P. T.-W. (2018) "The role of dry port in hub-andspoke network under Belt and Road Initiative", Maritime Policy \& Management, 45(3), pp. 370-387. https://doi.org/10.1080/03088839.2017.1396505

Wilmsmeier, G., Monios, J., Lambert, B. (2011) "The directional development of intermodal freight corridors in relation to inland terminals", Journal of Transport Geography, 19(6), pp. 1379-1386. https://doi.org/10.1016/j.jtrangeo.2011.07.010 